\title{
Randomized dose-escalation trial of elamipretide in adults with primary mitochondrial myopathy
}

Neurology ${ }^{\circledR}$ 2018;91:986. doi:10.1212/WNL.0000000000006635

In the article "Randomized dose-escalation trial of elamipretide in adults with primary mitochondrial myopathy" by Karaa et al., ${ }^{1}$ the supplemental figure was incorrectly referenced in the text. Figure e-1 should be referenced after table 1 under "Efficacy findings" on page e1215, and the first sentence on page e1216 should read: "...with the greatest apparent benefit for participants with a relatively shorter distance walked at baseline in a dose-dependent manner (data not shown; figure e-1, links.lww.com/WNL/A308)." The authors regret the error.

\section{Reference}

1. Karaa A, Haas R, Goldstein A, Vockley J, Weaver WD, Cohen BH. Randomized dose-escalation trial of elamipretide in adults with primary mitochondrial myopathy. Neurology 2018;90:e1212-e1221.

\section{Diffuse Lewy body disease manifesting as corticobasal syndrome}

A rare form of Lewy body disease

Neurology ${ }^{\circledR}$ 2018;91:986. doi:10.1212/WNL.0000000000006586

In the article "Diffuse Lewy body disease manifesting as corticobasal syndrome: A rare form of Lewy body disease" by Kasanuki et al., ${ }^{1}$ there were errors in figure 1 of the ahead-of-print version published online on June 13, 2018. The title for figure 1 should have read "Quantitative neuropathologic methods" rather than "Digital quantification of $\alpha$-synuclein and tau burden in the motor cortex," as originally published. The corrected figure includes new panel labels, A.a and A.b, and the corrected caption now includes "(A.a) $\alpha$-Synuclein immunohistochemistry (left) and digital pathology mask (right); (A.b) Phospho-tau immunohistochemistry (left) and digital pathology mask (right). For digital pathology, red indicates positive signal.” In addition, the in-text citation on page e 274 should have cited figure $1 \mathrm{~B}$ rather than figure $1 \mathrm{C}$. The final version of the article with all corrections was published online on July 17, 2018. The authors regret the errors.

\section{Reference}

1. Kasanuki K, Josephs KA, Ferman TJ, et al. Diffuse Lewy body disease manifesting as corticobasal syndrome: a rare form of Lewy body disease. Neurology 2018;91:e268-e279. 


\title{
Neurology
}

\section{Randomized dose-escalation trial of elamipretide in adults with primary mitochondrial myopathy}

Neurology 2018;91;986

DOI 10.1212/WNL.0000000000006635

This information is current as of November 19, 2018

\author{
Updated Information \& \\ Services \\ including high resolution figures, can be found at: \\ http://n.neurology.org/content/91/21/986.1.full \\ References \\ This article cites 1 articles, 1 of which you can access for free at: \\ http://n.neurology.org/content/91/21/986.1.full\#ref-list-1 \\ Permissions \& Licensing \\ Information about reproducing this article in parts (figures,tables) or in \\ its entirety can be found online at: \\ http://www.neurology.org/about/about_the_journal\#permissions \\ Reprints \\ Information about ordering reprints can be found online: \\ http://n.neurology.org/subscribers/advertise
}

Neurology ${ }^{\circledR}$ is the official journal of the American Academy of Neurology. Published continuously since 1951, it is now a weekly with 48 issues per year. Copyright (O 2018 American Academy of Neurology. All rights reserved. Print ISSN: 0028-3878. Online ISSN: 1526-632X.

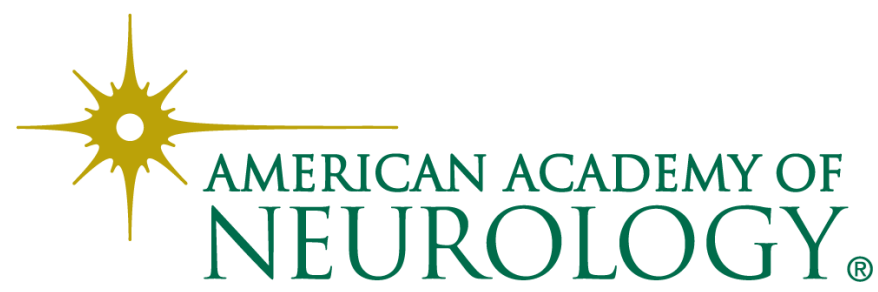

